\title{
Health Risk Assessment for Heavy Metals in Natural Cold-Bicarbonated Mineral Water, Wudalianchi
}

\author{
Z. H. Xie, J. H. Wang, Y. Liu, and C. Yang
}

\begin{abstract}
Natural cold-bicarbonate mineral water is rich in varies of trace elements in Wudalianchi, northern China. In this paper, heavy metals' (HMs) concentrations were measured. Furthermore, the health risk assessment of risk index (RI) and hazard quotient (HQ) was calculated. According to the dates, the average risk order were $\mathrm{Ni}>\mathrm{Fe}>\mathrm{Mn}>\mathrm{Ba}>\mathrm{Cu}>\mathrm{Hg}>\mathrm{Zn}$ for South Spring and $\mathrm{Ni}>\mathrm{Fe}>\mathrm{Mn}>\mathrm{Hg}>\mathrm{Ba}>\mathrm{Cu}>\mathrm{Zn}$ for North Spring. The risk level was lower than the maximum acceptable value recommended by International Commission on Radiological Protection (ICRP) $5.0 \times 10^{-5} \mathrm{a}^{-1}$. The $\mathrm{HQ}$ values of $\mathrm{Ba}, \mathrm{Cu}, \mathrm{Hg}$ and $\mathrm{Zn}$ were $<1$, but the $\mathrm{HQ}$ values of $\mathrm{Ni}, \mathrm{Mn}$ and $\mathrm{Fe}$ were $>1$. The results indicated that cold-carbonated mineral water wasn't potable water for daily drinking.
\end{abstract}

Index Terms-Health risk assessment, heavy metals, mineral water, Wudalianchi

\section{INTRODUCTION}

People pay more attention to drinking water quality nowadays [1]. Natural spring is pure, unpolluted and rich in varies of microelement [2]. Some springs contain special mineral ions [3], and they are regarded as medical water [4]. So it becomes more and more popular in the field of drinking water. There are many kinds of HMs derived from natural dissolved in mineral water, and lots of researches indicated that excessive HMs enter in the water would cause risk for human health [5].

Health risk assessment (HRA) has been recognized as a useful tool for identifying health risks of human activities [6]. It involves identifying the potential of a risk source to introduce risk agents into the environment, estimating the amount of risk agents that come into contact with the human-environment boundaries [7], and quantifying the health consequence of exposure [8]. Carcinogenic or non-carcinogenic methods can be used to assess potential health risk caused by HMs [9]. Non-cancer risk assessment methods based on Hazard Quotient (HQ) and Hazard Index (HI) are set by United States Environmental Protection Agency. With the rapid development of industry, researchers pay more attentions to HMs contaminations in water and their effects on human health [10]. For human being, appropriate amount of HMs like copper $(\mathrm{Cu})$, zinc $(\mathrm{Zn})$, iron $(\mathrm{Fe})$, manganese $(\mathrm{Mn})$ contribute to normal body growth and functions of living organisms [11], while the high

Manuscript received January 3, 2013; revised March 1, 2013.

Z. H. Xie, J. H. Wang and C. Yang are with the Institute of Volcano and Spring of Heilongjiang Academy of Sciences, Wudalianchi, China (e-mail: xianchi@xianchi.com, wangjinghua2001@163.com, yangchen0505@126. com).

Y. Liu is with the Heilongiiang Academy of Sciences, Harbin, China (e-mail:happyavi@163.com). concentrations of other metals like cadmium (Cd), chromium $(\mathrm{Cr})$, nickel $(\mathrm{Ni})$ and lead $(\mathrm{Pb})$ are considered highly toxic for human and aquatic life [12].

However, so far few research works have been, to our knowledge, conducted on HMs contaminations in mineral water and their effects on human health [13]. The natural cold-carbonated mineral water is one famous resource in Wudalianchi, which is considered of medical action to human. The objectives of this research were determined the HMs concentrations in mineral water and its potential health risk assessment.

\section{MATERIALS AND MethodS}

\section{A. Study Area Description}

Wudalianchi World Geopark is located in the north central Heilongjiang Province, China, at the intersection between Lesser Khingan Mountains and Songnen Plain. Its geographic coordinates is longitude $126^{\circ} 00^{\prime}-126^{\circ} 26^{\prime}$ east and latitude $48^{\circ} 34^{\prime}-48$ north. Fourteen young and old volcanoes stand in the 1060 square kilometers geopark, with their eruption ages ranging from 2.07 million years prehistory to 280 years before now. The area is characterized by cold temperature continental climate and the annual average rainfall is about $500 \mathrm{~mm}$. There are hundreds of natural mineral springs pouring from underground; it can be seen from the Fig 1.

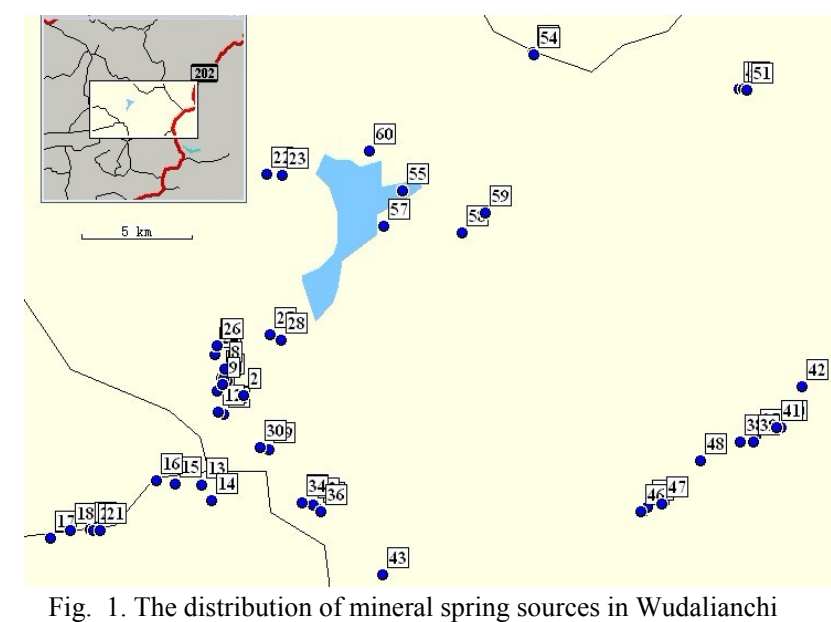

The South Spring and North Spring which are the typical mineral spring resources are located $1.3 \mathrm{~km}$ south east of the Medical Spring Mountain, near the Bailong River west to Shilong; the South Spring is located to the east of the river and the North Spring to the west, about 0.5 kilometer away.

\section{B. Sample Collection and Analysis}


On the basis of spring distribution and utilization degree, two spring resources i.e. South Spring and North Spring were selected for water sampling. According to the rainfall varied with seasons, twelve representative water samples (1L each) were collected during 2010 and 2011 in April, September and December. The mineral water samples were collected in cleaned plastic bottles pre-washed with $20 \%$ nitric acid $\left(\mathrm{HNO}_{3}\right)$ and double distilled water. Bottled water samples were directly taken from containers and filtered. Five drops of 1:3 diluted nitric acid was added to acidify the sample $(\mathrm{pH}<2)$. All samples were transported to the laboratory in cooled containers and stored in the fridge at $4{ }^{\circ} \mathrm{C}$ until analyses.

All filtered and acidified mineral water samples were analyzed for $7 \mathrm{HMs}(\mathrm{Hg}, \mathrm{Ni}, \mathrm{Fe}, \mathrm{Mn}, \mathrm{Ba}, \mathrm{Cu}, \mathrm{Zn})$ by using atomic absorption spectrometer (Purkinje General, TAS-900 Super AFG) under standard operating conditions. In view of data quality assurance, each sample was analyzed in triplicate and after every 7 samples two standard. The reproducibility was found to be at $99 \%$ confidence level.

\section{Health Risk Assessment}

The hazards caused by HMs can be divided into two groups for calculating numerical estimates of risk: carcinogenic and non-carcinogenic. The hazard quotient (HQ) for non-carcinogenic risk can be calculated by the following equation, as in (1)

$$
\mathrm{HQ}=\mathrm{CDI} / \mathrm{Rfd}
$$

where, according to USEPA database the oral toxicity reference dose values (Rfd) are 2.0E-02, 8E-01, 1.4E-01, 2.0E-01, 5.0E-03, 3E-04, 3.0E-01 mg/kg·day for Ni, Fe, Mn, $\mathrm{Ba}, \mathrm{Cu}, \mathrm{Hg}$ and $\mathrm{Zn}$.

The risk index (RI) of non-carcinogenic can be calculated by the equation, as in (2)

$$
\mathrm{RI}=\left(1 \times 10^{-6} \mathrm{CDI}\right) / \mathrm{Rfd}
$$

The chronic daily intake (CDI) through water ingestion was calculated according to the modified equation, as in (3)

$$
\mathrm{CDI}=(\mathrm{C} \times \mathrm{DI} \times \mathrm{EF} \times \mathrm{EP}) /(\mathrm{BW} \times \mathrm{AT})
$$

where, C, DI, EF, EP, BW and AT represent the concentration of $\mathrm{HMs}$ in water $(\mathrm{mg} / \mathrm{L})$, average daily intake rate $(2 \mathrm{~L} /$ Day), exposure frequency $(365 \mathrm{~d} / \mathrm{a})$, exposure period $(70 \mathrm{a})$, body weight $(60 \mathrm{~kg})$ and average life span (25550 d), respectively.

\section{RESUlTS AND Discussion}

\section{A. Water Characteristics}

Wudalianchi mineral water is oxygen-and-carbon-based bicarbonates low-temperature iron spring; it is a composite mineral water. The content of free carbon dioxide in natural mineral water is about $1000-2000 \mathrm{mg} / 1$; therefore it tastes cool and delicious like soft drinks and it can dissolve many kinds of ions.

Table I and Table II summarize the HMs concentrations in mineral water which collected from South Spring and North Spring sites.

Nickel concentrations in South Spring ranged from 0.248 to $0.283 \mathrm{mg} / \mathrm{L}$, while in North Spring it ranged from 0.085 to $0.272 \mathrm{mg} / \mathrm{L}$. The highest Ni concentration was observed in April and the lowest concentration was observed in September. Iron concentrations are very higher than other HMs' concentrations in both two springs, obviously. The concentrations ranged from 33.4 to $43.03 \mathrm{mg} / \mathrm{L}$ and 36.8 to $45.8 \mathrm{mg} / \mathrm{L}$ in South Spring and North Spring, respectively. Manganese concentrations in South Spring mineral water samples ranged from 3.69 to $6.77 \mathrm{mg} / \mathrm{L}$, and 4.49 to 9.77 $\mathrm{mg} / \mathrm{L}$ in North Spring. The highest concentrations and the lowest concentrations are observed in September and December of Fe and Mn. It can be seen that these two HMs' concentrations affected by the rainfall.

\begin{tabular}{|c|c|c|c|c|c|c|c|}
\hline & \multirow{2}{*}{\multicolumn{3}{|c|}{2010}} & \multirow{2}{*}{\multicolumn{3}{|c|}{2011}} \\
\hline & & & & & & & \\
\hline & & APR. & SEP. & DEC. & APR. & SEP. & DEC. \\
\hline \multirow{2}{*}{$\mathrm{Ni}$} & data & 0.265 & 0.283 & 0.265 & 0.248 & 0.260 & 0.248 \\
\hline & mean & \multicolumn{6}{|c|}{0.262} \\
\hline \multirow{2}{*}{$\mathrm{Fe}$} & data & 36.9 & 38.5 & 43.0 & 36.0 & 33.4 & 35.6 \\
\hline & mean & \multicolumn{6}{|c|}{37.23} \\
\hline \multirow{2}{*}{$\mathrm{Mn}$} & data & 5.38 & 4.89 & 6.77 & 4.91 & 3.69 & 5.95 \\
\hline & mean & \multicolumn{6}{|c|}{4.37} \\
\hline \multirow{2}{*}{$\mathrm{Ba}$} & data & 0.278 & 0.215 & 0.294 & 0.245 & 0.195 & 0.380 \\
\hline & mean & \multicolumn{6}{|c|}{0.268} \\
\hline \multirow{2}{*}{$\mathrm{Cu}$} & data & 0.003 & 0.003 & 0.005 & 0.003 & 0.002 & 0.005 \\
\hline & mean & \multicolumn{6}{|c|}{0.003} \\
\hline \multirow{3}{*}{$\mathrm{Hg}$} & data & 0.000 & 0.000 & 0.000 & 0.000 & 0.000 & 0.000 \\
\hline & data & 152 & 122 & 152 & 152 & 167 & 152 \\
\hline & mean & \multicolumn{6}{|c|}{0.000150} \\
\hline \multirow{2}{*}{$\mathrm{Zn}$} & data & 0.069 & 0.067 & 0.079 & 0.052 & 0.059 & 0.064 \\
\hline & mean & \multicolumn{6}{|c|}{0.065} \\
\hline
\end{tabular}

TABLE I: MinERAL WATER QUALITY MONITORING DATA, SOUTH SPRING $(\mathrm{MG} / \mathrm{L})$

$\mathrm{Hg}$ concentrations ranged from 0.000122 to 0.000167 $\mathrm{mg} / \mathrm{L}$ in South Spring, and 0.000109 to $0.000170 \mathrm{mg} / \mathrm{L}$ in North Spring. Ba concentrations ranged from 0.195 to 0.380 $\mathrm{mg} / \mathrm{L}$ in South Spring, and 0.455 to $0.848 \mathrm{mg} / \mathrm{L}$ in North Spring. $\mathrm{Cu}$ concentrations ranged from 0.0018 to 0.0052 $\mathrm{mg} / \mathrm{L}$ in South Spring, and 0.00050 to $0.00092 \mathrm{mg} / \mathrm{L}$ in North Spring. Zn concentrations ranged from 0.052 to $0.079 \mathrm{mg} / \mathrm{L}$

\begin{tabular}{|c|c|c|c|c|c|c|c|}
\hline & & \multirow{2}{*}{\multicolumn{3}{|c|}{2010}} & \multirow{2}{*}{\multicolumn{3}{|c|}{2011}} \\
\hline & & & & & & & \\
\hline & & APR. & SEP. & DEC. & APR. & SEP. & DEC. \\
\hline \multirow{2}{*}{$\begin{array}{c}\mathrm{N} \\
\mathrm{i}\end{array}$} & data & 0.103 & 0.235 & 0.221 & 0.085 & 0.272 & 0.133 \\
\hline & mean & \multicolumn{6}{|c|}{0.175} \\
\hline \multirow{2}{*}{$\begin{array}{l}\mathrm{F} \\
\mathrm{e}\end{array}$} & data & 41.2 & 41.2 & 45.8 & 39.4 & 36.8 & 40.0 \\
\hline & mean & \multicolumn{6}{|c|}{40.7} \\
\hline \multirow{2}{*}{$\begin{array}{l}\mathrm{M} \\
\mathrm{n}\end{array}$} & data & 8.29 & 6.70 & 9.77 & 7.45 & 4.49 & 7.87 \\
\hline & mean & \multicolumn{6}{|c|}{7.43} \\
\hline \multirow{2}{*}{$\begin{array}{l}\mathrm{B} \\
\mathrm{a}\end{array}$} & data & 0.701 & 0.615 & 0.848 & 0.455 & 0.491 & 0.698 \\
\hline & mean & \multicolumn{6}{|c|}{0.635} \\
\hline \multirow{3}{*}{$\begin{array}{l}\mathrm{C} \\
\mathrm{u}\end{array}$} & data & 0.000 & 0.000 & 0.000 & 0.000 & 0.000 & 0.000 \\
\hline & Cata & 79 & 80 & 92 & 50 & 72 & 78 \\
\hline & mean & \multicolumn{6}{|c|}{0.00063} \\
\hline \multirow{3}{*}{$\begin{array}{c}\mathrm{H} \\
\mathrm{g}\end{array}$} & data & 0.000 & 0.000 & 0.000 & 0.000 & 0.000 & 0.000 \\
\hline & Uata & 152 & 109 & 170 & 156 & 156 & 152 \\
\hline & Mean & \multicolumn{6}{|c|}{0.000149} \\
\hline \multirow{2}{*}{$\begin{array}{l}\mathrm{Z} \\
\mathrm{n}\end{array}$} & data & 0.025 & 0.037 & 0.055 & 0.021 & 0.035 & 0.044 \\
\hline & mean & \multicolumn{6}{|c|}{0.0362} \\
\hline
\end{tabular}
in South Spring, and 0.021 to $0.055 \mathrm{mg} / \mathrm{L}$ in North Spring.

TABLE II: MiNERAL WATER QUALITY MONITORING DATA, NORTH SPRING 
In the study area, the $\mathrm{HMs}$ concentrations of $\mathrm{Hg}, \mathrm{Ba}, \mathrm{Cu}$, $\mathrm{Zn}$ were very low and they were within the permissible limits of Drinking Natural Mineral Water standard GB 8537-2008 and Standards for Drinking Water Quality GB 5749-2006, it is listed in Table III. However, the HMs concentrations of Ni, $\mathrm{Fe}$ and $\mathrm{Mn}$ are higher than the limited values of standards.

TABLE III: LIMITED VALUE INDEX OF WATER QUALITY (MG/L)

\begin{tabular}{ccc}
\hline \hline $\mathrm{Ni}$ & GB 8537-2008 & GB 5749-2006 \\
\hline $\mathrm{Fe}$ & 0.02 & 0.02 \\
$\mathrm{Mn}$ & & 0.3 \\
$\mathrm{Ba}$ & 0.4 & 0.1 \\
$\mathrm{Cu}$ & 0.7 & 0.7 \\
$\mathrm{Hg}$ & 1.0 & 1.0 \\
$\mathrm{Zn}$ & 0.001 & 0.001 \\
& & 1.0 \\
\hline \hline
\end{tabular}

\section{B. Human Health Risk Assessment}

Local residents enjoy drinking the natural cold bicarbonate mineral water which pouring from the South Spring and North Spring. The basic information about amount of drinking water, age, body weight, drinking habits were collected by interviewing or reported. Therefore, the streams that were used for drinking purpose were also selected for HMs risk assessment.

TABLE IV: RISK INDEX (RI) AND HAZARD QUOTIENT (HQ) INDICES OF HMS OF SOUTH SPRING AND NORTH SPRING

\begin{tabular}{|c|c|c|c|c|}
\hline & \multicolumn{2}{|c|}{ " South Spring } & \multicolumn{2}{|c|}{ "North Spring } \\
\hline & $\mathrm{RI}\left(\mathrm{a}^{-1}\right)$ & HQ & $\mathrm{RI}\left(\mathrm{a}^{-1}\right)$ & HQ \\
\hline $\mathrm{Ni}$ & $4.36 \mathrm{E}-06$ & 4.37 & $4.28 \mathrm{E}-06$ & 4.28 \\
\hline $\mathrm{Fe}$ & $1.55 \mathrm{E}-06$ & 1.55 & $1.69 \mathrm{E}-06$ & 1.69 \\
\hline $\mathrm{Mn}$ & $1.25 \mathrm{E}-06$ & 1.25 & $1.77 \mathrm{E}-06$ & 1.77 \\
\hline $\mathrm{Ba}$ & $4.47 \mathrm{E}-06$ & 0.04 & $1.1 \mathrm{E}-07$ & 0.11 \\
\hline $\mathrm{Cu}$ & $2.26 \mathrm{E}-08$ & 0.02 & $4.84 \mathrm{E}-10$ & 0.005 \\
\hline $\mathrm{Hg}$ & $1.65 \mathrm{E}-08$ & 0.016 & $1.65 \mathrm{E}-08$ & 0.016 \\
\hline $\mathrm{Zn}$ & 7.2E-09 & 0.007 & 3.99E-09 & 0.004 \\
\hline
\end{tabular}

Table IV summarizes the calculated RI values and HQ values for consumption of drinking mineral water. The calculated results show that in Wudalianchi area, where people have drunk the South Spring and North Spring mineral water contaminated with $\mathrm{HMs}$, the RI values were 7.2 E-09, 1.65 E-08, 2.26 E-08, 4.47 E-06, 1.25 E-06, 1.55 E-06, $4.36 \mathrm{E}^{-06} \mathrm{a}^{-1}$ for $\mathrm{Zn}, \mathrm{Hg}, \mathrm{Cu}, \mathrm{Ba}, \mathrm{Mn}, \mathrm{Fe}, \mathrm{Ni}$, and 3.99E-09, 1.65E-08, 4.84E-10, 1.1E-07, 1.77E-06, 1.69E-06, 4.28E-06 $\mathrm{a}^{-1}$ for $\mathrm{Zn}, \mathrm{Hg}, \mathrm{Cu}, \mathrm{Ba}, \mathrm{Mn}, \mathrm{Fe}, \mathrm{Ni}$, respectively. The risk level was lower than the maximum acceptable value recommended by International Commission on Radiological Protection (ICRP) $5.0 \times 10^{-5} \mathrm{a}^{-1}$.

HQ indices of HMs through consumption of mineral water in the South Spring and North Spring for $\mathrm{Zn}, \mathrm{Hg}, \mathrm{Cu}, \mathrm{Ba}, \mathrm{Mn}$, $\mathrm{Fe}, \mathrm{Ni}$ were $0.007,0.016,0.02,0.04,1.25,1.55,4.37$ and $0.004,0.016,0.005,0.11,1.77,1.69,4.28$, respectively. Therefore, the HQ indices of HMs in the study area were found in the order of $\mathrm{Ni}>\mathrm{Fe}>\mathrm{Mn}>\mathrm{Ba}>\mathrm{Cu}>\mathrm{Hg}>\mathrm{Zn}$ for South Spring and $\mathrm{Ni}>\mathrm{Fe}>\mathrm{Mn}>\mathrm{Hg}>\mathrm{Ba}>\mathrm{Cu}>\mathrm{Zn}$ for North Spring. The HQ values of $\mathrm{Ba}, \mathrm{Cu}, \mathrm{Hg}$, and $\mathrm{Zn}$ were $<1$, it was safe to drink. However, the HQ values of $\mathrm{Ni}, \mathrm{Fe}, \mathrm{Mn}$ were $>1$, it indicated that it was risk to drink the mineral water as daily drinking.

\section{CONCLUSION}

Two natural cold bicarbonate mineral water sites, South Spring and North Spring, were studied in this paper. The concentrations of HMs like $\mathrm{Ni}, \mathrm{Fe}, \mathrm{Mn}, \mathrm{Ba}, \mathrm{Cu}, \mathrm{Hg}, \mathrm{Zn}$ had been detected. The RI and HQ values had been calculated and the human risk had been assessed. The results indicated that the HQ indices of HMs in the study area were found in the order of $\mathrm{Ni}>\mathrm{Fe}>\mathrm{Mn}>\mathrm{Ba}>\mathrm{Cu}>\mathrm{Hg}>\mathrm{Zn}$ for South Spring and $\mathrm{Ni}>\mathrm{Fe}>\mathrm{Mn}>\mathrm{Hg}>\mathrm{Ba}>\mathrm{Cu}>\mathrm{Zn}$ for North Spring. HQ values of $\mathrm{Ni}, \mathrm{Fe}, \mathrm{Mn}$ were $>1$, it indicated that it was risk to drink the mineral water as daily drinking. And the local residents should pay more attention about it.

\section{ACKNOWLEDGMENT}

This work was financially supported by the Heilongjiang Academy of Science Research Foundation and Heilongjiang Province Science Technology Plan Foundation.

\section{REFERENCES}

[1] O. W. Lau and S. F. Luk, "A survey on the composition of mineral water and identification of natural mineral water," International Journal of Food Science and Technology, vol. 37, pp. 309-317, April 2002.

[2] W. H. Bruvold, "Mineral taste and the potability of domestric water," Water Research Pergamon Press, vol. 4, pp. 331-340, November 1969.

[3] S. Vassileva, "Mineral water and Spas in Bulgaria," Clinics in Dermatology, vol. 14, pp. 601-605, 1996.

[4] J. E. Bernstein, "Dermatologic aspects of mineral water," Clinics in Dermatology, vol. 14, pp. 567-569, 1996.

[5] P. Kavcar, A. Sofuoglu, and S. C. Sofuoglu, "A health risk assessment for exposure to trace metals via drinking water ingestion pathway," International Journal of Hygiene and Environmental Health, vol. 212, pp. 216-227, May 2009.

[6] T. E. Deventer, R. Saunders, and M. H. Repacholi, "WHO health risk assessment process for static fields," Progress in Biophysics and Molecular Biology, vol. 87, pp. 355-363, November 2004.

[7] Y. J. Yi, Z. F. Yang, and S. H. Zhang, "Ecological risk assessment of heavy metals in sediment and human health risk assessment of heavy metals in fishes in the middle and lower reaches of the Yangtze River basin," Environmental Pollution, vol. 159, pp. 2575-2585, January 2011.

[8] M. L. Huang, S. L. Zhou, B. Sun, and Q. G. Zhao, "Heavy metals in wheat grain: assessment of potential health risk for inhabitants in Kunshan, China," Science of the Total Environment, vol. 405, pp. 54-61, June 2008.

[9] F. F. Agneta, H. Annika, V. Katarina, W. Margareta, and M. Wallen, "Assessment factors - Applications in health risk assessment of chemicals," Environmental Research, vol. 104, pp. 108-127, December 2006.

[10] S. Muhammad, M. T. Shah, and S. Khan, "Health risk assessment of heavy metals and their source apportionment in drinking water of Kohistan region, northern Pakistan," Microchemical Journal, pp. 334-343, March 2011.

[11] F. K. Zhu, W. X. Fan, X. J. Wang, L. Qu, and S. W. Yao, "Health risk assessment of eiht heavy metals in nine varieties of edible vegetable oils consumed in China," Food and Chemical Toxicology, pp. 1-5, September 2011.

[12] M. L. Hung, S. Y. Wu, Y. C. Chen, H. C. Shih, Y. H. Yu, and H. W. Ma, "The health risk assessment of $\mathrm{Pb}$ and $\mathrm{Cr}$ leachated from fly ash monolith landfill," Journal of Hazardous Materials, vol. 172, pp. 316-323, July 2009.

[13] R. baciocchi, S. Berardi, and I. Verginelli, "Human health risk assessment: Models for predicting the effective exposure duration of on-site receptiors exposed to contaminated groundwater," Journal of Hazardous Materials, vol. 181, pp. 226-233, May 2010. 


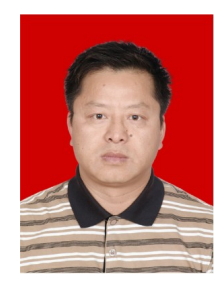

Z. H. Xie was born in Wudalianchi in 1962 . He graduated from Harbin University of Commerce, and his major is food science.

He works in Institute of Volcano and Spring, Heilongjiang Academy of Sciences in Wudalianchi as a professor of engineering. Study on the utilization of volcanic mud and mineral water resources in Wudalianchi.

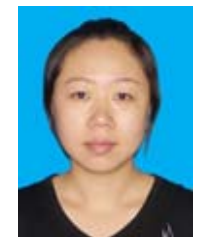

J. H. Wang was born in Wudalianchi in 1982. She graduated from Heilongjiang University, and got Master's degree in organic chemistry in July 2008.

She works in Institute of Volcano and Spring, Heilongjiang Academy of Sciences in Wudalianchi as a research assistant. Study on the utilization and assessment of Wudalianchi volcanoes and mineral water resources. Component analysis of water quality, development of spring products and assessment of mineral water are researched.

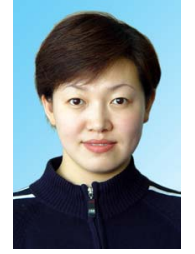

Y. Liu was born in Harbin on May 14th 1975. She graduated from Harbin Institute of Technology, and got a Master's degree in MBA in 2005.

She worked in Heilongjiang Academy of Science as an associate researcher.

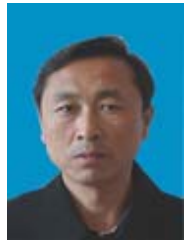

C. Yang was born in Wudalianchi in 1964. He graduated from Heilongjiang Institute of Commerce, and his major is food process.

$\mathrm{He}$ works in Institute of Volcano and Spring, Heilongjiang Academy of Science in Wudalianchi. Study on the utilization of mineral water resources in Wudalianchi. 